$\star$ Rhizomes: Cultural Studies in Emerging Knowledge: Issue 34 (2018)

\title{
The Regulation of the Subject by the Technology of Time
}

\author{
Maxwell Kennel ${ }^{[1]}$
}

Abstract: Beginning from the entangled categories of the human and the technological, this exploration surveys thinkers who concern themselves with problems of technology and time, seeking to examine how the confluence of technology and time regulate and condition the formation of subjectivity. Drawing on Bernard Stiegler's work in Technics and Time, Augustine's Confessions, and the myth of Prometheus, the following draws out the technological character of time and makes suggestions about how to reconceptualize these different temporalizing technologies after the critique of capitalism.

Surely technology, in its ever-changing form and forms, is a pharmakon that has been with us from the start. Regardless of whether we speak of technology or technologies or the broader field of techne (a practice or craft), it remains that the term 'technology' refers to something that, like a double-edged sword, helps us and harms us, something that we use and that uses us, and something that is at once politically charged (often subtly oriented toward particular interests and ends with particular benefactors), yet ambivalent, taking different sides at different times (and therefore available for us to use as means for our own ends). ${ }^{[2]}$ Although it is at our disposal and supposedly outside of ourselves, some have argued that technology is not in fact something extra that is added onto our human nature and experience, but instead something inextricably related to both humanity and history, and indeed something that challenges the legitimacy of these categories. In this vein, David Wills has speculated that technology may indeed go back to our dorsality, and the fact that we have bodies that are capable of reaching down to pick up tools in the first place. ${ }^{[3]}$ Under these conditions, the question is not how technology and humanity are different or similar, but how we are always already relating to technology, and how technology conditions our experiences and contributes to the formation of our subjectivity. This co-invention of humanity and technology what the French philosopher Bernard Stiegler in his Technics and Time calls the "invention of the human,"[4] and which this essay explores - is not just a spatial condition of our existence, but it is also something that is entwined with our experience of time.

The following study surveys several thinkers who concern themselves with the problems of technology and time, seeking to examine how technology and time condition the formation of our subjectivity. Below I resource thinkers who both fall into and escape the categories of continental philosophy, Christian theology, and media studies - and I do so in an effort to undertake a postsecular inquiry that takes seriously both the critique of the secular and the critique of Christianity (understanding that neither of these critiques are the concern of this study, but rather form the context of the combination of thinkers whose work is addressed). Reflection on the lived experience of technology and time, both distinctly and in their confluence, is not limited to discourses on philosophy, theology, or technology, but happens in interdisciplinary ways at their intersection and in the context of the political economy of time in which time and money are converted into each other - a movement that involves conversions and debts that are not purely secular or religious, but always both in combined and uneven ways.

If we consider our lived experience of time, as subjects who are subject to the throes of time, we may discover that our calendars themselves are a kind of technology. As we mark the passage of time, dividing one day from the next, morning from evening from noon from night, we use calendars as tools to separate and discern one moment or temporal period from another, ultimately contributing to the formation of the self (the individuated identity of the 
being that says "I..." or "I have..." or "I will..."). The formation of the self as we know it inherits the regulae of monastic life epitomized in the Rule of St. Benedict, but is also indebted to the mechanized regulation of temporal life beginning with the industrial revolution (labor time, time conditioned by capital). ${ }^{[5]}$ Our week is divided into seven days, each of which bear the name of ancient gods, and these names are marks of our ancient debt. Our debt to industrialization, however, is not found in these names themselves, but in our division of weeks into weekdays and weekends, and the division of our days into sleep time, labor time, and leisure time, and the ensuing repetitive cycle. In these divisions do we not see a kind of technology that itself is the result of the formative power of technology? ${ }^{[6]}$

In and by its pharmakonic nature, technology conditions the human experience of time - perhaps even conditioning time itself, depending on whether one's metaphysics permits a notion of time in-itself. To shed light on this technological-temporal conditioning of human experience we need only observe an oft noted but nonetheless fundamental set of distinctions between different kinds of time derived from the names of Greek gods: chronos time, or the quantitative chronological time of the ticking clock that we all have present on our cellphones (or perhaps still on our watches); kairos time, that time when we happen upon the right moment and actualize things in a way that could only take place at the right place and the right time (resulting in a fortunate, or perhaps providential, confluence of spatiality and temporality); and finally the aion time that (like Eliade's illud tempus) is experienced in transcendence or eternity when we are taken out of the time of timelines and experience some altogether other sense of temporality.

In his Deep Time of the Media, Siegfried Zielinski asks "Who owns time?" and suggests that the political economy of time - its "structure, rhythm, and the design of its intensity" - is at issue for us precisely because time is at the disposal of those in power. ${ }^{[7]}$ To understand time, Zielinski uses the aforementioned distinctions between chronos time (the "time of history" that "cripples us because we are not made of enduring stuff and we shall pass"), kairos time ("the auspicious moment" that "challenges us to make a decision"), and aion time ("that stretches far, far beyond the lifespan of humans and planet Earth") in order to show how media condition the human experience of time. ${ }^{[8]}$ From the freezing of time in photography, to the shrinking of communication time in telegraphy and telephony, to the reproduction of time in phonography, to the compartmentalization and repeatability of time in television, to the contemporary culmination of media in computers and the internet - Zielinski's an-archaeology of media suggests that all media is "time media" (although Zielinski would not agree with Stiegler's assessment of the co-invention of human and technology, for he does not believe that humanity and technology have a common origin). ${ }^{[9]}$

Although I make much of the distinctions between chronos, kairos, and aion in what follows, I have not endeavored to replicate the precision of the ancient roots of these words, preferring instead to use the terms to signal contemporary temporal phenomena in a way that employs chronos as an indicator of measure, duration, and periodization (understanding that the Greek term predates industrialization); kairos as indicating a sort of singular and qualitative timeliness and timelessness (understanding that the rhetoricians also mobilized kairos instrumentally as a means in the pursuit of persuasion); and aion as a signature for transcendence and eternity outside all measurement of time (understanding that the ancient Greek sense of aion is fundamentally different than the now predominant Christian sense of eternity).

Caveats aside, under this model it is easy to think of examples of the kind of time that chronos names, for it is an integral part of much of our technology, which is almost omnipresent, and it is a fundamental part of capitalist labor time. We are never far from a clock, and we are never far from the anticipation of further predictable, regulated chronos time. This kind of time is reliable and constant, being only a measurement of consistent consecutive intervals. It provides us with certainty, allows us to control and regulate ourselves and our lives, and perhaps in return we accept its nearly divine ubiquity and omnipresence as a natural state of affairs. But this kind of time is anything but natural. 
Against the naturalized power of chronos time, it is perhaps more difficult for us to think of examples of kairos time, to the point where we may find it very difficult to pinpoint a time when we are not 'on the clock' or when the clock is not physically upon us in the form of a cellphone or watch (making demands, reminding, distracting), much less a time when an external clock high on the wall is not watching us like some sovereign manager. However, despite being subject to chronos time, we may also notice that there are punctuating moments or peak experiences that resist the advance of what began as simple measured time but has become the valorization of the power of measurement. Despite our regularly being conditioned by chronos time, there remain some common examples of when we escape the clutches of chronos time. For instance, in a particularly good conversation one can loose track of time and become lost in the subject matter, taking one's time to patiently understand and listen to the other. Or, in a romantic situation one can lose track of time in the gaze of the other, and in doing so no longer be under the totalizing influence of the consistency of the ticking seconds on the clock. ${ }^{[10]}$ Musicians and athletes also talk about this experience of what Csikszentmihalyi calls 'flow,' citing the loss of measured time-consciousness that can be experienced in the midst of improvisation or play, and in this example we see the confluence of both kairos as timely action (hitting the right note at the right time) and kairos as a step outside of the regime of chronos time (losing oneself in the music). A further example of the coincidence of play with the deregulation of temporal experience can be found in Raphaël Zarka's history of skateboarding, a book which contains both a chronology and a reflection on how the ludic experience of skateboarding reconditions the participants' experience of time and space. ${ }^{[11]}$

Where examples of kairos time occur with exemplary clarity, I think, is in their coincidence with aion time in the context of religious experiences. One might consider a theological example like messianic time, a time that runs in the opposite direction of secular time (that is, if we believe the claims of Walter Benjamin's Theological-Political Fragment), ${ }^{[12]}$ or apocalyptic time which negotiates between the proportions of pleromatic (full), kenomatic (empty), and metaxic (between) time. ${ }^{[13]}$ Given the connection between religion and consciousness of human finitude, we can see that outside the regulations and divisions of chronos time are messianic or apocalyptic moments of kairos time that may contain within them any number of ticking seconds (perhaps even just one!), and these ticking seconds (being the smallest available measurement of time) are, in many ways, both a reminder of the inevitability of death and an admonition to anticipate death.

This is where Bernard Stiegler re-enters our meditation on the technology of time, stating that, for Martin Heidegger "thanatology is technics" meaning that in the context of Heidegger's concept of Dasein as being-towards-death, "technology opens up the rapport with death." [14] Stiegler points out that "in this technics there is a pharmacology," that is, in technology there is a hindrance and a help, a poison and a cure, a wound and a healing, but is there something between or beyond these two options? This link between death and technology runs deep in human experience precisely because technology is inseparable from human life and human death. ${ }^{[15]}$

Indeed, the first volume of Stiegler's Technics and Time advances the claim that human beings are always-already intertwined with what he calls "technics." Stiegler calls technics the 'unthought' in philosophy. He argues that philosophy has "repressed technics as an object of thought" ( $T T, \mathrm{I}, \mathrm{ix})$, and asserts that technical evolution has always occurred side-by-side with human evolution. To say 'side-by-side' is even misleading because, for Stiegler, we understand the human when we understand "the invention of the human" ( $T T, I, 134)$. The ambiguity of this term is essential, given that technology is invented by human beings and humans themselves are invented by their technology. Technics for Stiegler - used in a broad sense, and including language $(T T, I, 155)$, reading and writing, each understood as prostheses $(T T, \mathrm{I}, 198)$ - is defined as "the pursuit of life by means other than life" $(T T, I, 17)$. One of the most glaring consequences of the human-techne chiasmus, which has been around since the beginning, is the idea of technics as time $(T T, 1,83)$.

In the second and third volumes of Technics and Time Stiegler strays from the question of the invention of the human, while also continuing to build upon it. In Disorientation Stiegler explores the meaning of epimētheia (hindsight/afterthought) for today, drawing from it a critique of speed and advancement as "essential attribute[s]" of technics $(T T, I, 63)$. Suggesting that "[t]oday, technical speed must confront this delay" of Epimetheus, Stiegler 
argues that we must consider time as something "apart from the clock, as capital" (TT, II, 63). Later in the same volume, Stiegler continues this critique by asking "What does technology promise us?" and suggesting that part of technological promise is the organization of memory, and the notion that memory can be externalized in media, from reading and writing to television $(T T, \mathrm{Il}, 133)$. Amidst his other concerns in his expansive three-volume work, Stiegler continues his concern for the critique of certain configurations of time in the most recent volume, Cinematic Time and the Question of Malaise [mal-être]. For Stiegler, part of our present mal-être is quite simply that we do not turn off the television and pick up a book, because television conditions our experience of time (and our ontological determination by time) in a way that is inferior to the book (TT, III, 9-11). Stiegler is concerned with the problem of memory, for all technology is a kind of "memory-support" that extends memory outside of the self as a kind of prosthesis (TT, III, 67 and 131).

Stiegler makes it explicit throughout the volumes of his magnum opus that he is not merely conjugating the question of technics with the question of time, but showing how the two have been conjugal from the start. It is not so simple for Stiegler that the subject is the human being, and the object is technology, and that the two are intertwined. Instead, in $\S 3$ of the first volume of Technics and Time Stiegler troubles these waters by suggesting that the subject and object are in an undecidable relationship, a kind of indiscernibility of the 'who' and the 'what.' Foucault's notion of the regulated subject, lurking behind the title of this investigation, is not entirely at odds with Stiegler's intentional confusion of subject and object, for Foucault does not conceive of the subject apart from the regulating powers that surround and determine it. The subject is defined by both its being-governed by powers that surround it, and its rejection of being-governed by that power through the resisting means of critique. ${ }^{[16]}$ This undecidable relationship between being regulated by an overdetermining power and opposing this governing force, in some ways seems to mirror the one that Stiegler calls the invention of the human, in which human beings use technology and are used by technology.

This is what I mean by the conditioning of the human perception of time by technology, or 'the regulation of the subject by the technology of time.' In the context of the intertwining and intercontamination of humanity and technics, we can join Stiegler in identifying technology with time, not only because technology is the only means by which we can measure time (up to our present standards of measurement, that is), but also because different attitudes toward, and uses of, different technologies encourage correspondingly different experiences of time. Here we can return to a concrete example like the clock, which Stiegler writes of again in the context of Heidegger:

The clock measures time (or change) by comparing the duration of an event "to identical sequences on the clock and can thereby be numerically determined," which it can only do as "a physical system in which an identical temporal sequence is constantly repeated"... At the end of 24 hours, it is the first hour that returns. How could a clock mark anything beyond its 24 hours? Because it only functions for Dasein, a who, who collects or re-marks the return of the cycle. (TT, I, 21)

Stiegler notes that Dasein is "the guarantor of being" and defined by its temporality, self-understanding, and historicity which is also its facticity $(T, \mathrm{I}, 5)$. This facticity, in particular, is associated (by Stiegler) with calculation, "which is organized by facticity as an essential trait of technics - [which] ... is the falling of existence" $(T T, I, 6,125)$. The ambiguity present in the phrase 'the invention of the human' serves as the link between human evolution and technical evolution, both of which share a beginning. For Stiegler this origin takes the form of a fall $(T T, I, 125)$, arising at least in part out of technics and its over-extension. I suggest that this fall is at least partially the result of an orientation toward the calculative thinking of chronos time (with all of its love of prediction and foresight), and away from the meditative thinking of kairos time (with its timeliness and timelessness), or aion time (with its mystical experience of eternity). ${ }^{[17]}$

With these distinctions between chronos, kairos, and aion in mind, and the technological formation of time before us, we can now turn to the central illustration of the first volume of Technics and Time. Stiegler's book intervenes in the drama of the sons of the Titan lapetus: Prometheus, whose foresight prompted him to steal fire from the gods on mount Olympus; and Epimetheus, whose hindsight only led to withdrawal and forgetting $(T T, I, 16,185)$. Where 
Stiegler uses the story of these brothers in his examination of memory and forgetting, I suggest that we can also look to them to understand the regulation of the subject by the technology of time, specifically the fall brought on by the technological (and perhaps thanatological) edging-out of karios and aion time by a certain configuration of chronos time.

Where Prometheus becomes the god of technics by bringing fire to humanity, Epimetheus' forgetting inspires retrospection and delay $(T T, \mathrm{I}, 184)$. Distracted from the possibility of effective action, Epimetheus is very different from his brother Prometheus who acts so decisively. But decision also tends to be forgetful, and Stiegler cautions us not to write off Epimetheus, for he is "not simply the forgetful one, the figure of essential witlessness that makes up all experience (since what happens, what has passed, must, as past, be ruminated); he is also the one who is forgotten." (TT, I, 186). Although Epimetheus is at fault because of his forgetfulness, he may still be worth our time.

How do the aforementioned distinctions between different experiences of time map onto the myth of Prometheus and Epimetheus? Surely not in an exact fashion, but just as surely in a helpful way. In Aeschylus's rendition, Prometheus is punished by Zeus for stealing fire from Hephaistos, and put in chains. ${ }^{[18]}$ In his tortured state, Prometheus is unheard and disempowered $(65,75)$, crying out in agony $(108,129)$. Having stolen power from the Gods and given it to human beings (125), mortals who live and die have now become glorified (163) and been taught the arts (169-170). A salvific figure (350), Prometheus the hero prevented humans from foreseeing their own deaths, gave them blind hope, and gifted them with fire (374-378). He invents the wisdom of numbers and the memory of letters for humanity (660-664) and yet, he is unable to free himself of his own bonds (683). The chorus responds: "You've been tortured, humiliated, so that your mind / wanders / driven to distraction." (684-686). The first prophetic enlightener of humanity (730), Prometheus is driven to distraction, but not defined by it.

On the other hand, in Plato's rendition of the myth in the Protagoras (320-322), Epimetheus is the distracted one whose attention was not on humanity but on the animals. The god of afterthought, brother to the god of forethought, Epimetheus gets distracted from one thing and attends to another, eventually running out of qualities and leaving humans naked. Plato suggests that this initial fault is what prompted Prometheus to steal fire, and goes on to develop his view of what Vernant calls "the technical sphere's social function."[19] Where Prometheus rightly allocates his attentions, even while experiencing distraction, Epimetheus does not.

In light of this founding myth of technics, could we say (on one hand) that Prometheus steals fire because he is conscious of chronos time, for he is thinking-ahead and time-conscious enough to plan for the future and therefore must understand the sequential measurement of time, while (on the other hand) Epimetheus is unaware of this chronology and forgets his task of clothing human beings? Or should we say instead that it is Prometheus who embodies kairos time, for he found his opportune moment to steal the beginnings of techne? Both of these associations have limitations, but both elucidate Stiegler's reading of the two sons of lapetus.

The problematic relationship between time, humanity, death, and technology with which we are concerned may become clearer in light of these associations, given that many contemporary discourses value the calculated violence of speed over the potential peace of slow conduct. ${ }^{[20]}$ The connection between these figures, unexplored by Stiegler (indeed by his own friendly admission ${ }^{[21]}$ ), is made here suggestively and not exhaustively. While we may argue that Epimetheus cannot be representative of kairos time because he missed the opportune moment to clothe human beings and forgot his task, I suggest that it would be too easy to write off this connection simply because Epimetheus did not seize the moment, for kairos time by its very nature also challenges the idea that time itself is something to be seized like a tool or commodity or mobilized instrumentally toward an end (although, in light of the opportunistic and exploitative conditioning of time by capital, we may be tempted to consider kairos time to be the right moment to be decisive and buy the right stocks or advance one's career). The time of kairos is surely decisive and opportune, but it need not be capitalist like the measuring chronology of chronos time has largely become.

Stiegler's point is that Epimetheus deserves further consideration, and I suggest that this is true especially because his forgetfulness speaks critically to the contemporary obsession with successful and effective action, and our 
ignorance of the meaning and value of failure, and our certainty about the conditions that demarcate both success and failure. If our subjectivity is regulated by the technology of time, we may find ourselves between the predictive and forward thinking impulse of Prometheus and the tendency toward distraction in Epimetheus, struggling to prevent our consciousness of the past, present, and future from clouding our vision of the present moment that so often occurs in the blink of an eye. However, periodizing our experience in such a way that divides time into past, present, and future, and recapitulates each into the present yet fleeting moment may itself be a capitulation to the regulating controls of chronos time, depending on how it is done. Periodization is always political, and reflects the interests and power held by those who periodize, whether that is the power of intellectual history in the grand periodization that divides the medieval era from secular modernity, or the power of the self in the periodization of one's life narrative that divides childhood, from adolescence, from adulthood, from old age. [22] If we are sensitive to the political ways in which we periodize the time of our world, then we should ask: what forms of resistance and critique can be found to oppose the governing control and love of power that are permitted or even encouraged by chronos time?

One answer to this question that takes seriously the theological roots of many modern concepts, can be found by looking to Augustine's Confessions. At the conclusion of his autobiography - which is indelibly marked the construction of subjectivity with the guilt and release of confession as a technology of self ${ }^{[23]}$ - Augustine sets forth his account of time as an extension or distention of the mind (distentio animi) (XI, 26), noting that this extension that is also a kind of distraction (XI, 29). The term that Augustine uses to describe time is distentio, which has been interpreted negatively by some, given its resonance with other terms in the Confessions such as dispersion (distantibus) and divergence (distendunt) $(\mathrm{XI}, 23){ }^{[24]}$ Struggling with his inability to measure time, Augustine confesses that time is a distentio in the soul (animus), crying out to God "what is it that I am measuring?" (XI, 26). Later in Book XI, Augustine again uses the term distentio again, but this time it is to confess his guilt: "my life is a kind of distraction [ecce distentio est vita mea]" (29). This connection between distention and distraction in Augustine's usage of the term may seem inconsequential, but it may yet tell us something about our experience of time and our situation between attention and distraction, especially when we consider the further resonance with 'confusion' that Hammond points out in Augustine's writing. ${ }^{[25]}$ Indeed, in this section of the Confessions Augustine is concerned with how he ought to direct his attention and will toward those things that God requires: "Leaving behind my former times, I recollect myself and follow the One. I forget what is past, and instead of being distracted I reach out, not for what is in the future and so transitory, but for those things which are before me: I press forward, going in the right direction, rather than being distracted [distentionem] to the prize of my highest calling." (XI, 29).

Setting aside for the moment the fact that many disagree about the normative foundations of what this right direction is, it remains that Augustine's confessed experience of time indicates a rich set of resonances between the extension and distraction of our attentions. ${ }^{[26]}$ This idea that our experience of time is conditioned by distraction as well as attention resonates with both the attention of Prometheus and the distraction of Epimetheus. Stiegler writes that "In order to make up for the fault of Epimetheus, Prometheus gives humans the present of putting them outside themselves" ( $T T, \mathrm{I}, 193)$, but can we not observe that this extension risks giving humanity over to the discontents of chronos time, whether in the insistence on anticipating and controlling the future or in the distraction from what we truly hold to be important? Prometheus' gift turns out to be no gift at all when it is taken as a rule. Where Augustine locates the experience of time within the soul (animus), Prometheus gives humanity the gift of externalizing time through the measurements of techne, and between these inner and outer explanations of time and technology we are so often caught. Where Augustine understands time as inhering in and extending outwards from the animus, Stiegler understands time as something caught up in the co-invention of humanity and technology, and yet both Stiegler and Augustine understand memory as something not restricted to inner experience, but externalized (for Stiegler memory is externalized in the prosthesis of technics, and for Augustine memory is externally located in an expansive field outside the self [Confessions X, 12]). 
In this struggle to situate time and memory, surely it is not a question of replacing chronos time with karios time, or of privileging attention over distraction in a principled way, but I contend that our contemporary situation is far from balanced or well-proportioned, and I suggest (in the spirit of Stiegler's critique of malaise) that we are in need of a reordering of our attentions and a revaluation of the value of technology, specifically in its ability to condition our experience of time.

Returning to the connection between death and technology, in our terms (which are not Stiegler's) we could say that by distinguishing between chronos, kairos, and aion time we are brought into a rapport with death precisely because chronos time reminds us that we are limited, while in the latter two kinds of time we forget our finitude and touch something eternal or atemporal. Despite the fact that in chronos time our memory is assisted by predictable periodizations of time (in what year were you born?) and exteriorized in the prostheses of writing and digital media (Augustine's written autobiography, my iPad calendar), and despite that in kairos or aion time we experience memorable moments that may not be attached to a particular time and place (remember when...?), it remains the case that it is chronos time that encourages us to remember that our time is limited (made up of countable increments) and kairos and aion time that create environments in which we forget that we are all running out of time.

While consciousness of finitude is essential, especially given the perspective it affords, the regulative tendency of chronos time cannot be ignored. The scarcity of time in our culture of speed further identifies our general experience of time with the particular type of temporal conditioning that chronos time names. In our time, technology skews the human experience of time towards the chronos, often monetizing our time and creating what Stiegler elsewhere calls an 'attention economy' focused on chronos time. ${ }^{[27]}$ Time can only be turned into money when it is reduced to neutral and consistent counters, and so the monetization of time is ensured when our experience of time is restricted to chronos time. Our measurement, regulation, and faithful adherence to chronos time too often comes at the expense of other senses of time, depriving us of not only religious experience, but to all valuable human experiences that do not occur under the watchful eye of the clock, an eye that continually reminds those under it that they should soon be returning to work, that is, if they are not already at work. [28]

Éric Alliez writes in his magisterial book Capital Times of "the conquest of time," and here we can observe that this formulation also mirrors the bi-directionality of the 'of' found in Stiegler's "invention of the human." [29] Alliez's formulation suggests that we have sought to subjugate time, but time has also subjugated us. Examining labor time and its exchangeability, Alliez studies the conversion of time into money (citing Benjamin Franklin's statement: "time is money!"). ${ }^{[30]}$ Although he does not explicitly critique chronos as a name for a particular experience of time, Alliez does address Plotinus' use of aion in the third Ennead, and critiques the commodification of time, while noting the tragic dimension of kairos time, describing it as "the final moment when destiny turns toward misfortune" with reference to the work of Pierre Aubenque. ${ }^{[31]}$ Although these terms for Alliez do not bear the same weight that they do here, his critique resonates with the critique outlined above. He writes that money itself has become "a temporal reserve," exploring the genealogy of money and its relationship with time by exploring the works of Aristotle, Augustine, and Marx. ${ }^{[32]}$

With both the invention of the human and the conquest of time in mind, we might observe that the conversion of time into money is evident in late capitalist society when we seek to 'buy some time' by paying for technologies that will speed up our travel time or productivity in such a way that will make us more efficient thereby adding 'value' to our lives (value that is so often reconverted into more money in the ongoing desire for accumulation). Alliez may have his own thoughts on how much Augustine's distensio animi owes to Plotinus, but his critique of the commodification and monetization of (labor) time are helpful. ${ }^{[33]}$

In Augustine, both attention and distraction are conditioned by the expectation or anticipation of divine providence, with attention encouraging one to remember God and distraction promoting the forgetting of one's divine vocatio. The human desire for domination and pleasure remains frustrated, and this defines the temporal regulation of the subject by both the regretful 'already' and the desiring 'not-yet' in conversion. ${ }^{[34]}$ Speaking to this part of the 
Confessions, Alliez narrates a journey "[b]etween the expectatio that is synonymous with distentio and the extensio that belongs to the memoria Dei, to the dynamics of the inner person's intentio gathering oneself together to follow the One - when the Two dominates." [35] Citing Confessions XI, 12 Alliez notes the "impossible character" of striving towards consciousness of eternity, seeming to suggest that we are always drawn back into distraction. [36] But we should be clear that distraction both serves and resists capitalized time. On one hand, we might become distracted from the quotidian plodding of chronos time by something that takes us out of that sphere of regulation, thereby liberating us from measured and predictable time and bringing us to the experience of something new. ${ }^{[37]}$ On the other hand, we may become distracted from these new and exceptional experiences, being drawn back into consciousness of the capitalist idea that time is money, and when we lose track of time we are wasting money. This both results in and is symptomatic of a simultaneously financial and existential anxiety, a consciousness of our material precarity that again relates to our awareness of human finitude. [38]

And so distraction is not the magic key, for like technology it can work for us or against us. Instead, if we are interested in emancipating ourselves from the industrialization of time, then we must cultivate modes of resistance that undercut capital time. At the end of his book Governing by Debt Maurizio Lazzarato's suggestion is to refuse work and thereby reject the acceleration of time. He writes that 'We need 'time,' but a time of rupture, a time that arrests the 'general mobilization,' a time that suspends apparatuses of exploitation and domination - an 'idle time."'[39] This idle time, for Lazzarato, must refuse traditional divisions of labor like the debtor-creditor relationship or the worker-boss relationship, and instead transform these social relations. This applies to new forms of human capital, and the exploitation of human knowledge and skill by universities and corporations (to cite just two examples). ${ }^{[40]}$ This kind of refusal of work - inherited from Virno and the autonomia movement - is not the refusal to go to work to feed one's family, but an epistemic refusal that disrupts labor time to begin with, an act of resistance that "interrupts the course of time (and history), establishing a before and after that affect subjectivity first of all." [41] Against the sacrifice of one's life to time as it is conditioned by capital, Lazzarato suggests that this refusal can subvert capital by developing a kind of time that is in-between speed and slowness, and he suggests that technology can help us do this when machines are "freed from the hold of valorization." [42] But how do we free machines from their regulation by capitalized chronos time? Lazzarato does not give an explicit answer. Part of reimagining temporal experience outside of the overdetermining forces of industrialized technological time will no doubt require that attention and political action be reevaluated in light of new media, especially considering the suggestion by Byung-Chul Han that new media technologies work counter to the interests of democracy and civil society. [43]

To recapitulate, in conclusion we can observe that the conditioning of time by the terms chronos, kairos, and aion as well as the tension between Promethean memory and Epimethean forgetting - each seem to be present within the human being as a set of generative or creative tensions. However, as Stiegler, Alliez, and Lazzarato each observe, problems emerge when these tensions become maligned, or worse yet, subject to commodification and industrialization. Chronos time has not always been measured time, so given to the present capitalist conversion of time into money, but according to the ancient Greeks it has its origin in the founding of the cosmos. Chronos births the universe in an egg which splits into land and sky, and the ensuing mythology "correspond[s] with a period of difficulty and anxiety regarding the representation of time."[44]

A remaining problem with the conditioning of the human experience of time by Greek terms is the assumption that these principles are the only (or even the primary) determiners of the human experience of time, rather than just certain western or European experiences. Although it is a descriptive fact that these Greek terms have conditioned much human experience of time because of the orientalist positioning of the west as the dominant reference point in the master discourses of academe, this description should not be mistaken for a defensible prescription. In Yuk Hui's The Question Concerning Technology in China we are given a new vision of a plurality of technics beyond the western field, and this cosmotechnical world challenges the colonial interpretations of technology and time by presenting us with the simple fact that there are other viewpoints besides the Greek senses of time, although Hui provides much more than the mere suggestion that there are many myths of technical origin, and seeks to move 
even beyond postcolonial critique by adopting a standpoint that is at once materialist and also cosmological and historical. ${ }^{[45]}$ Hui argues against 'Prometheanism' and its assumption "that all cultures arise from techne, which is originally Greek." [46] Instead, Hui points to the various mythologies of China in which there is no Promethean figure, and argues for a cosmotechnics that takes seriously the idea that "[s]cientific and technical thinking emerges under cosmological conditions that are expressed in the relations between humans and their milieus, which are never static."[47]

In light of the embeddedness of human understandings of technics within cosmological contexts, as Boris Groys points out, it is important to name that our understanding of technology must now account for a new cosmology in which the questions and answers that human beings ask are no longer simply empirical, religious, rationalistic, or libidinal, but conditioned by the Internet and the value-laden ways in which Google regulates the dialogue between human and world. Whether we have questions for the world or we think the world has questions for us, Groys argues that now "our dialogical behavior is defined by the specific rules and ways in which the questions can be asked and answered within the framework of the Internet." [48] If our dialogue with the world is fundamentally changing, then so too is our temporal experience. Given this sea change in the invention of the human, it is the contention of this essay that we need a concept of technics that is not fully identified with 'chronos time' nor the commodification of time by capital. As Lazzarato says: "we need another way of living time,"[49] but what new ways of making time livable are available in the contemporary political economy?

\section{Notes}

1. This essay began as a presentation at the Society for Literature, Science, and the Arts meeting held in Kitchener, Ontario on September 2011. Thanks to Bernard Stiegler for his initial encouragement in 2011, to Davin Heckman for his suggestions for expanding the text, and to P. Travis Kroeker, Marcel O'Gorman, and Alexander Galloway for their various comments on the present version.

2. See George Grant, "The Computer Does Not Impose on Us the Ways it Should be Used" [1976] in The George Grant Reader. Ed. William Christian and Sheila Grant (Toronto: University of Toronto Press, 1998), 418-434. Grant writes: "Technology is not something over against ontology; it is the ontology of the age. It is for us an almost inescapable destiny. The great question is not then 'the race between technology and ontology,' but what is the ontology which is declared in technology? What could it be to be 'beyond' it, and would it be good to be 'beyond' it?" (431). See also Arthur Kroker, Technology and the Canadian Mind: Innis/McLuhan/Grant. (Montréal: New World Perspectives, 1984).

3. David Wills, Dorsality: Thinking Back Through Technology and Politics. Posthumanities 5 (London: University of Minnesota Press, 2008).

4. Bernard Stiegler, Technics and Time, Vol. 1, The Fault of Epimetheus. Trans. George Collins and Richard Beardsworth (Stanford, CA: Stanford University Press, 1998); Technics and Time, Vol. 2, Disorientation. Trans. Stephen Barker (Stanford, CA: Stanford University Press, 2009); Technics and Time, Vol. 3, Cinematic Time and the Question of Malaise. Trans. Stephen Barker (Stanford, CA: Stanford University Press, 2011). All further citations to follow in-text citing volume and page number.

5. See John Durham Peters, "Calendar, Clock, Tower" in Deus in Machina: Religion, Technology, and the Things In Between. Ed. Jeremy Stolow (New York: Fordham University Press, 2013), 25-42.

6. See Lewis Mumford, Technics and Civilization (London: Routledge, 1934), 12-17.

7. Siegfried Zielinksi, Deep Time of the Media: Toward an Archaeology of Hearing and Seeing by Technical Means. Trans. Gloria Custance (Cambridge, MA: MIT Press, 2006), 29-31.

8. Ibid.

9. Ibid, 31 and 6 .

10. See Roland Barthes, A Lovers Discourse: Fragments. Trans. Richard Howard (London: Cape, 1979), 129131. 
11. Raphaël Zarka, On A Day With No Waves: A Chronicle Of Skateboarding 1779-2009 (Paris: Editions B42, 2011), 109-134.

12. Walter Benjamin, "Theological-Political Fragment" in Selected Writings, Volume 3, 1935-1938. Edited by Howard Eiland and Michael W. Jennings (Cambridge, MA: Belknap, 2002), 305-306.

13. Cyril O'Regan, Theology and the Spaces of Apocalyptic (Milwaukee, WI: Marquette University Press, 2009), 29.

14. Marcel O'Gorman and Bernard Stiegler, "Bernard Stiegler's Pharmacy: A Conversation” Configurations 18.3 (Fall 2010), 460.

15. See Marcel O'Gorman, “What is Necromedia?” Intermédialités 1 (2003).

16. Michel Foucault, "What is Critique?" in The Politics of Truth. Ed. Sylvère Lotringer and Lysa Hochroth (New York: Semiotext(e), 1997), 23-36.

17. See Martin Heidegger, Discourse on Thinking. Trans. John M. Anderson \& E. Hans Freund (New York: Harper and Row, 1959); Christian Fuchs, "Martin Heidegger's Anti-Semitism: Philosophy of Technology and the Media in the Light of the Black Notebooks" tripleC: Communication, Capitalism, and Critique 13.1 (2015).

18. Aeschylus, Prometheus Bound. Trans. Herrington and Scully (London: Oxford University Press, 1989). All citations to follow in-text by line number.

19. Jean-Pierre Vernant, Myth and Thought among the Greeks (New York: Zone Books, 2006), 268-269.

20. See Paul Virilio, Speed and Politics: An Essay on Dromology. Trans. Mark Polizzotti (New York: Semiotext(e), 2006), part 4.

21. Bernard Stiegler, Email Communication with the Author. October 9, 2011.

22. See Kathleen Davis, Periodization and Sovereignty: How Ideas of Feudalism and Secularization Govern the Politics of Time (Philadelphia: University of Pennsylvania Press, 2012).

23. Michel Foucault, "Subjectivity and Truth" in The Politics of Truth. Ed. Sylvère Lotringer and Lysa Hochroth (New York: Semiotext(e), 1997), 188-191.

24. See the helpful note on p 238 of Augustine, Confessions, Books 9-13. Edited and Translated by Carolyn J.-B. Hammond (Cambridge, MA: Harvard University Press/Loeb Library, 2016).

25. Ibid, 254 (footnote \#80).

26. The connection between Augustine's distentio animi and distraction is a subject of much debate in the study of Augustine. For an explanation that opposes this connection see Thomas L. Humphries, Jr. "Distentio Animi: praesens temporis, imago aeternitatis" Augustinian Studies 40.1 (2009): 75-101.

27. See Bernard Stiegler, Taking Care of Youth and the Generations. Trans. Stephen Barker (Stanford, CA: Stanford University Press, 2010) and Patrick Crogan and Samuel Kinsley, "Paying Attention: Towards a Critique of the Attention Economy" Culture Machine 13 (2012): 1-29.

28. See Antonio Negri and Michael Hardt, Labor of Dionysius: A Critique of the State-Form (Minneapolis: University of Minnesota Press, 1994). In the preface, the authors write of Marx's identification of labor, temporality, and fire in the Grundrisse, stating that "the work we are faced with in contemporary society, day in and day out, is seldom so joyful, but rather is characterized most often by boredom and tedium for some, and pain and misery for others. The endless repetition of the same of capitalist work presents itself as a prison that enslaves our power, stealing away our time, and the time it leaves us, our leisure time, seems to be filled merely with our passivity, our unproductivity. The labor we affirm must be grasped on a different plane, in a different time." Later, amidst the book's attempted recovery of labor as "living labor," Negri and Hardt also position subjectivity between human and machine (12-13).

29. Éric Alliez, Capital Times: Tales from the Conquest of Time. Trans. Georges Van Den Abbeele (Minneapolis: University of Minnesota Press, 1996), i.

30. Ibid, xv.

31. Ibid, 243 (note \#9).

32. Ibid, 5.

33. Ibid, 81.

34. In his final work, Lyotard ventriloquizes Augustine, writing of his libidinal 'not-yet' (19), his understanding of 
delay as "the sin of time" (27), and emphasizes the caesura in confessional writing between past and future (36). He writes: "The delay that throws the confessing I into despair is not due to a failure in its chronology; no, chronos, at once and in its entirety consists in delay." (17) See Jean-Francois Lyotard, The Confession of Augustine. Trans. Richard Beardsworth (Stanford, CA: Stanford University Press, 2000). See also David J. Depew, "Lyotard's Augustine" in Augustine for the Philosophers: The Rhetor of Hippo, the Confessions, and the Continentals. Ed. Calvin L. Troup (Waco: Baylor University Press, 2014), 59-76.

35. Alliez, Capital Times, 117.

36. Ibid, 118.

37. See Boris Groys, On the New. Trans. G.M. Goshgarian (London: Verso, 2014) 21-28.

38. See Isabell Lorey, State of Insecurity: Government of the Precarious. Trans. Aileen Derieg (London: Verso, 2015).

39. Maurizio Lazzarato, Governing by Debt. Trans. J.D. Jordan (New York: Semiotexte, 2015), 246.

40. Ibid, 248.

41. Ibid, 249.

42. Ibid, 250.

43. Byung-Chul Han, In the Swarm: Digital Prospects. Trans. Erik Butler. Untimely Mediations 3 (Cambridge, MA: MIT Press, 2017). Compare this negative evaluation of technology with that of Ray Brassier in "Prometheanism and its Critics" in \#Accelerate. Ed. Robin Mackay and Armen Avanessian (Falmouth, UK: Urbanomic/Merve Verlag, 2014). Against the leftist politics of time and its suspicion of technology, Brassier presents a Prometheanism that rejects supposedly 'theological' concerns about maintaining equilibrium between what is made and what is given (Arendt). Brassier argues that "[t]he Promethean trespass resides in making the given." [478]. See also Alexander Galloway, "Brometheanism" b2o.

http://www.boundary2.org/2017/06/alexander-r-galloway-brometheanism/

44. Vernant, Myth and Thought, 131.

45. Yuk Hui, The Question Concerning Technology in China: An Essay on Cosmotechnics. Mono 3 (Falmouth: Urbanomic, 2016), 17, 56-57.

46. Ibid, 14.

47. Ibid, 18.

48. Boris Groys, "Google: Words beyond Grammar." No. 046. dOCUMENTA (13) (2012), 5.

49. Lazzarato, Governing by Debt, 250.

\section{Cite this Essay}

https://doi.org/10.20415/rhiz/034.e06

RHIZOMES ISSN 1555-9998 $\star 230$ East Hall Bowling Green State University Bowling Green, OH 43403

Editors: Ellen Berry and Carol Siegel. Reviews editor: Craig J. Saper. Technical editor: Helen J Burgess 